Papers and Proceedings of the Royal Society of Tasmania, Volume 110, 1976

(ms, received 5.3 .1976 )

\title{
BIOSTRATIGRAPHIC NOMENCLATURE FOR LATE PALAEOZOIC ROCKS IN TASMANIA
}

by M.J. Clarke and N. Farmer

Geological Survey of Tasmania

(with five text-figures)

\section{ABSTRACT}

The Rekunian Series is proposed for part of the Late Palaeozoic (StephanianKazanian Stages) of Tasmania. It is divided into four stages which are, in ascending order, the Hellyerian, the Tamarian, the Bernacchian and the Lymingtonian. The Epoch embraces the we11-developed Tasmanian expression of the climax and retreat of the Gondwanan Late Palaeozoic glaciation, and witnesses the appearance and most prolonged development of the characteristic marine cold-water Eumdesma fauna anywhere in the. world.

The Hellyerian Stage, which is represented wholly by thick tillite, glaciolacustrine rhythmite clay and other glacigene rocks, is sparsely fossiliferous, but the available evidence indicates that it pre-dates the appearance of both Eumdesma and Glossopteris. The Tamarian, Bernacchian and Lymingtonian Stages are mostly represented by shallow-water marine deposits in which glacially derived dropstones are frequently abundant, but subordinate glacigene strata, coal measures and other freshwater rocks are also present. The basis for stage recognition rests essentially with the nature of successive marine macro-invertebrate assemblages which constitute the Eurydesma fauna, and partly, but much less importantly, with broad lithological considerations. Subsidiary microfloral data are used to supplement and complement the macrofaunal information.

General lithological characters, the low to very low taxonomic diversity of faunas and floras, and palaeomagnetic data (Irving 1966). which indicate a position close to the south magnetic pole for Tasmania during Permo-Carboniferous times, all consistently point to cool or cold conditions throughout the Rekunian Epoch.

\section{INTRODUCTION}

The last two decades have witnessed profound advances in our understanding of the stratigraphy of Tasmanian (and other Australian) Late Palaeozoic (Permo-Carboniferous) rocks. In Tasmania, the initial impetus was provided by students of the Geology Department, University of Tasmania under the guidance of M.R. Banks (Banks, in Spry and Banks 1962). In more recent years the momentum has been maintained by the continuing detailed systematic $1: 15840$ and $1: 12500$ mapping programme of the Geological Survey of Tasmania. During this latter period, much additional information has also accrued from fully cored siratigraphic bore holes, and certain large scale civil engineering projects undertaken by the Hydro-Electric Commission and Associated Pulp and Paper Mills Pty. Ltd. As a result, detailed lithostratigraphic information became available for much of Tasmania, but in comparison, systematic biostratigraphic studies were somewhat neglected (Dickins 1968; Runnegar 1969b). However, since 1967, particular attention has been concentrated in this area so that detailed biostratigraphic information is now available for several definitive sections, and broadly consistent faunal distributions have been established in all sequences ( $\mathrm{Clarke}$ and Banks 1975).

As work has progressed it has become increasingly apparent that most internationally accepted divisions of Late Palaeozoic time (based as they are on warm-water sequences characterised by an abundance of carbonates and evaporites associated with 


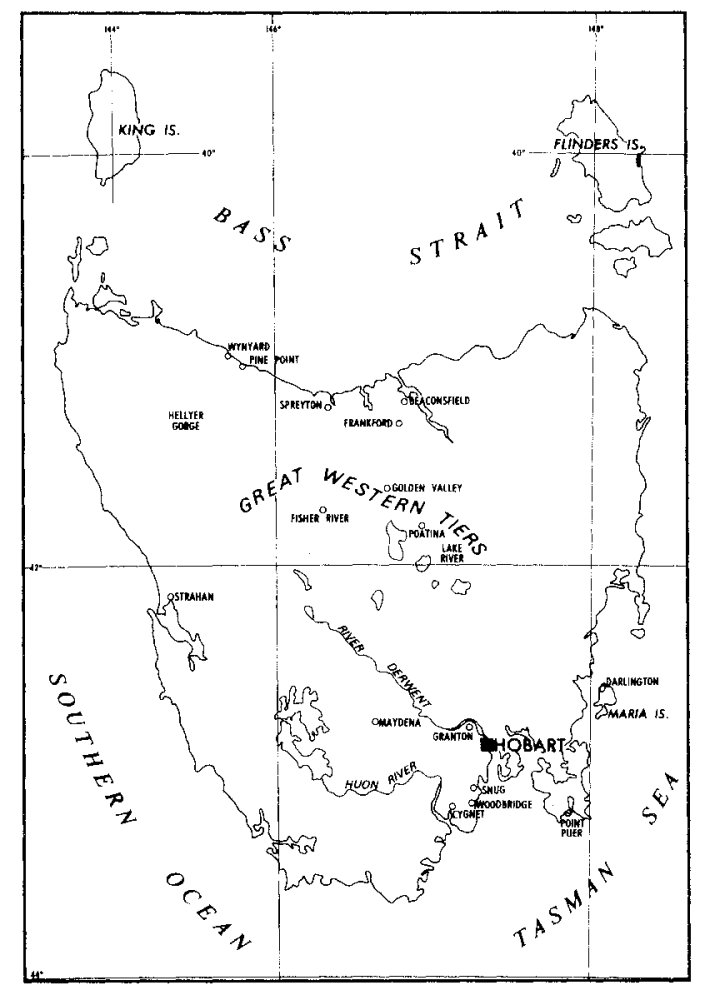

Fig. 1. - Map showing principal localities referred to in the text. diverse faunas which often contain reef-building corals, fusulinids and goniatites), cannot be applied with precision within the essentially coolto cold-water Gondwanan realm where sequences display an unmistakeable 'glacial imprint'. This latter consideration is particularly true with respect to the Tasmanian sequence. As a result, informal local biostratigraphic zonal schemes have been proposed with an ever increasing frequency for the various Australian sequences (Hil1 1952; Dickins 1963; Dickins et al. 1964; Runnegar 1967a; 1969b; Dear 1972a; Clarke and Banks 1975). Waterhouse $(1967,1969)$ has proposed formal chronostratigraphic nomenclature for the New Zealand Permian and most recently, Runnegar and $\mathrm{McClung}$ (1975), have outlined a broad synthesis for all eastern Australian sequences. In our view, such syntheses are premature. Whereas we concede a limited consensus concerning broad biostratigraphic correlations throughout eastern Australia and New Zealand, it is salutary to compare the major discrepancies which are apparent between correlations of the various eastern Australian and New Zealand sequences as proposed by Waterhouse $(1969,1970,1971)$, Runnega $r$ and McClung (1975), Clarke (1974), Dear (1972a), and Clarke and Banks (1975).

In view of these considerations, and now that the systematic description of Tasmanian faunas is about to commence, we consider that such description be best made within the framework of formal local biostratigraphic nomenclature. The various biostratigraphic units herein proposed are selected in accordance with the Austra1ian Code of Stratigraphic

Nomenclature (4th Edition, 1964 as revised 1973), Articles 39, 40 and 42, and the names have been registered with the Central Register of Australian Stratigraphic Names, maintajned at the Bureau of Mineral Resources, Canberra. It is our belief that the description of the Tasmanian faunas will proceed most expeditiously, and with least risk of misunderstanding, within this framework. It should be noted that the lithostratigraphic and biostratigraphic criterja used throughout this paper are essentially those which are more fully stated in Clalke and Banks (1975), but minor additions and amendments in keeping with more recent work are also included. Rather paradoxically the impending description of Tasmanian marine invertebrate faunas will require relatively few additional taxa. For example, one of the most characteristic species is the long-established Trigonotreta stokesi Koenig, 1825. This species was the first described Australian fossil taxon, and contrary to the statements of Armstrong (1968), is both morphologically 
and stratigraphically quite distinct from Grantonia hobartensis Brown, 1953. Other examples of long-established and valid Tasmanian taxa include Fisispirifer aviaula, Sulciplica tasmaniensis, Taeniothaerus subquadratus, Terrakea brachy thaera [= T. solida Etheridge and Dun\} Deltopecten Zimaeformis, D. squamuliferus, Etheripecter fittoni, Merismopteria macroptera and Stutchburia compressa (Morris in Strzelecki 1845); Wyndramia jukesi (Etheridge, 1880); Eurydesma hobartensis and Megadesmus grandis [as Notomya trigonalis] (Johnston 1887, 1888); and Keeneia tweZvetreesi (Dun, 1912). Most of the remaining forms are specifically comparable with material described more recently from elsewhere in Australia and New Zealand (Booker 1929; Hil1 1950; Crockford 1951; Maxwe11 1954; Dickins 1956, 1957, 1963; Fletcher 1958; Campbel1 1959. 1960, 1961, 1965; Runnegar 1965, 1967, 1969a, 1970, 1972; Wass 1968, 1969; Thomas 1971; Waterhouse 1964; 1968; Dear 1972b; Armstrong 1970; McClung and Armstrong 1975). Ali marine macro-invertebrate taxa recorded to date from the Rekunian Series are listed in Appendix 1.

\section{REKUNIAN SERIES}

Name:

The Rekunian Series is numed after Rekuna, south-eastern Tasmania. Rekuna was the Aboriginal name for the now extinct Tasmanian emu, a species which inhabited much of the terrain occupied by the outcrop of the Rekunian Series.

Relation to other sequences

The strata which comprise the Rekunian series are almost always sub-horizontal. They rest with profound landscape unconformity on a folded basement composed of Precambrian and early Palaeozoic rocks intruded by Late Devonian to Early Carboniferous granites (McDougall and Leggo 1965). Basement surfaces are often scoured, plucked and striated. The Rekunian Series is followed transitionally or paraconformably by subhorizonta1, wholly non-marine sequences which comprise the Upper Parmeener Super-Group (Forsyth et al. 1974) of Permo-Triassic age.

Subdivision

Four stages are recognised. They are, in ascending order, the Hellyerian, Tamarian, Bernacchian and Lymingtonian (fig. 2).

\section{HELLYERIAN STAGE}

Name

The stage is named after the Hellyer Gorge, north-western Tasmania.

Reference section

The section is the lower and middle parts of the Wynyard Tillite as exposed in the Hellyer Gorge. The sequence consists of thick tillite, with subordinate glaciolacustrine rhythmite clay, and minor turbidite sandstone layers.

Biota

Fossils, which are rare throughout the Hellyerian Stage, include anostracans, Gyrochorte, a megasecopteran insect, Tasmanadia twe Zvetreesi Chapman (interpreted as the trails of euthycarcinoid crustaceans by Riek (1973), Botrychiopsis [Rhacoptepis] plantiana (Carruthers), and a Stage 1 Potonieisporites Microflora (sensu Evans 1969; Helby 1969; Kemp 1975). A spinose acritarch Veryhachium occurs sparingly at Pine Point, Wynyard and at Strahan (Kemp pers. comm.), and lends support to the hypothesis of wetbase glaciers discharging their debris at or below sea-level as a mechanism for depositing large thicknesses of tillite (Carey and Ahmad 1961).

\section{Comments}

In view of the paucity of biota, the Hellyerian Stage is provisionally conceived as the total range of the Stage 1 Potonieisporites Microflora in the Hellyer Gorge 


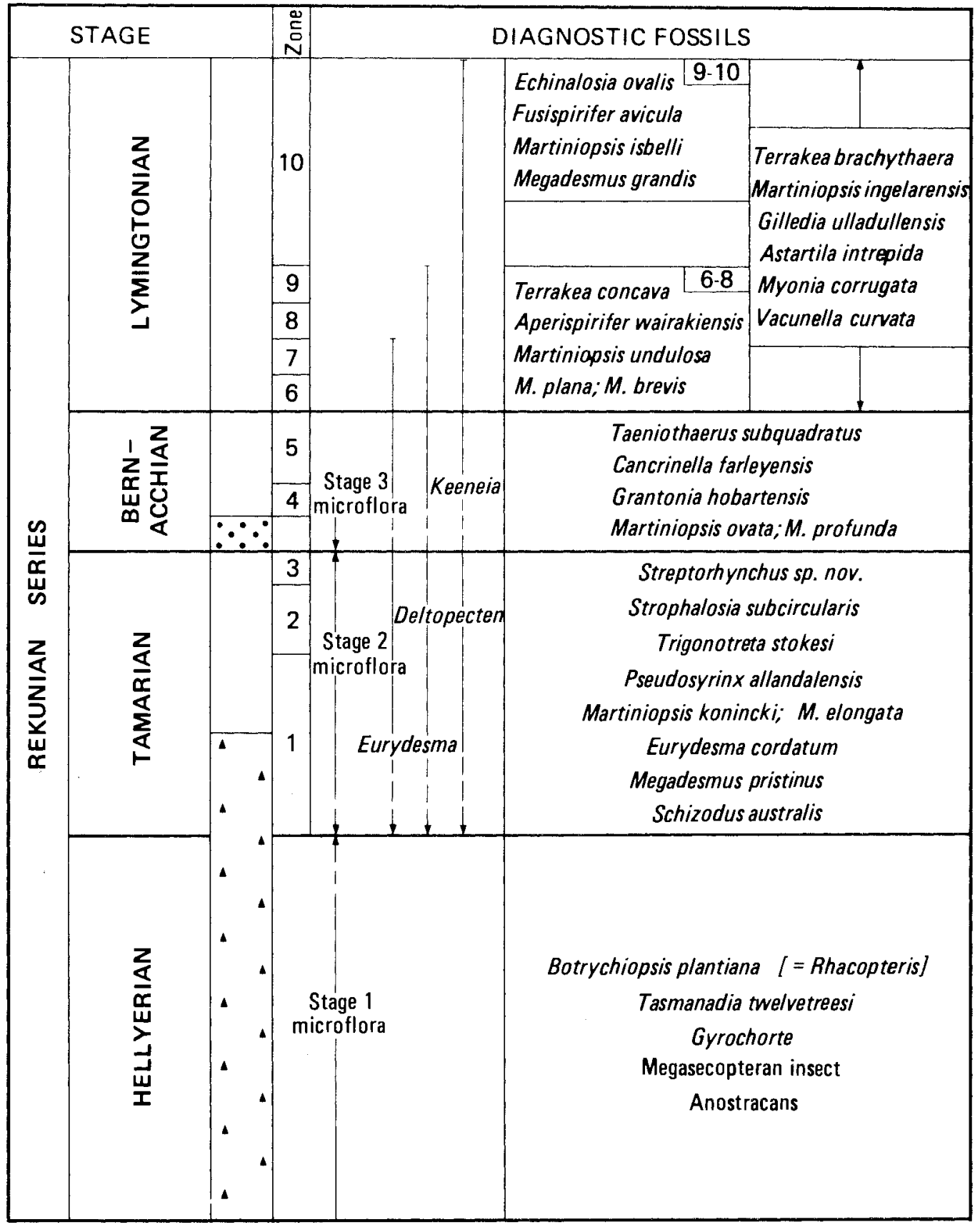

Fig. 2. - Stage subdivision of the Rekunian Series. In the generalised stratigraphic column the triangles represent tillite and other glacigene rocks, the dots represent coal measures and other freshwater rocks, and marine sequences with dropstones are left blank. 
section. Although the evidence is not conclisive, the Hellyerian Stage appears to represent an interval of time prior to the appearance of the Eumydesma-Glossoptemis association (see later).

Correlation and age

The Hellyerian Stage is the Tasmanian equivalent of the Stage 1 Potonieisporites Microflora elsewhere in eastern Australia. A Late Carboniferous (late Stephanian) age is assigned to the Stage 1 Potonieisporites Microflora by Evans (1969) and Helby (1969).

\section{Distribution}

Hellyerian biota are known only from the Wynyard Tillite in the Hellyer Gorge section, from near the base of the same formation at Pine Point near Wynyard, and in basal sequences of tillite and glaciolacustrine clay near Strahan, West Tasmania. However, it seems most probable that the lower parts of thick glacigene sequences in the Woodbridge-Cygnet area, the Maydena area, and the Lake River-Poatina area are also of Hellyerian age. All palynological residues so far obtained from the Woodbridge-Cygnet area have been much carbonised (Helby; Kemp pers. comm.), and the other sequences have yet to be sampled systematically.

\section{TAMARIAN STAGE}

Name

The name is derived from the Tamar River, northern Tasmania.

Reference section

The section is the Masseys Creek Group (Gee and Legge 1974) exposed in Andersons Creek and West Arm, near Beaconsfield, Tamar Valley. The sequence is wholly marine and consists of ill-sorted mudstone, siltstone and sandstone with abundant glacially derived dropstones, together with minor tillite, limestone and glauconitic sandstone. The lowest parts of the Andersons Creek and West Arm section are rather indifferently exposed, but closely similar successions through this interval have been recorded in two fully cored bore holes (Clarke, in Gee and Legge 1974). Whereas the section in Andersons Creek and West Arm cannot be regarded as complete and definitive in itself, all three Tamarian assemblage faunizones are present in undoubted superposition (fig. 3). These zones are, in ascending order:- the zone of Streptorhynchus sp. nov. with Megadesmus pristinus, the zone of Eurydesma cordatum, and the zone of Sulciplica sp. nov. The base of the Tamarian Stage occurs in the Hellyer Gorge section. It may be necessary to select individual Tamarian faunizone stratotypes away from the Andersons Creek and West Arm section. Particularly well-exposed, continuously fossiliferous coastal sections at Wheatleys Bay and Drip Beach, Huon River area, south-east Tasmania, and near Darlington, Maria Island, are all worthy of consideration.

Biota

Fossils are abundant throughout the Tamarian Stage which can be defined as the total range of (inter alia) Trigonotretx stokesi Koenig and the Stage 2 Microflora. other diagnostic forms include Streptorhynchus sp. nov., StrophaZosia subcircularis Clarke, Martiniopsis konincki Etheridge, M. elongata McClung and Armstrong, Pseudosyrinx alzandalensis Armstrong, Eurydesma cordatum Morris, Deztopecten waterfordi Dickins, Megadesmus pristinus Runnegar, Phestia darwini (de Koninck), Pyramus Zaevis (J. Sowerby) and Schizodus australis (Runnegar). A profusion of large, coarsely-ribbed Deltopecten, Eurydesma spp. and large Keeneia spp. is characteristic. Other forms include Sulciplica sp. nov., S. stutchburii Auctt, Etheripecten sp., Merismopteria sp., Myonia eZongata Dana, M. morrisi (Etheridge), Stutehburia spp., Peruvispira sp, Rhabdocantha sp., Calceolispongia, Camptocrinus, Jimbacrinus, rare conulariids, and a variety of bryozoans, but most of these persist beyond the Tamarian Stage. By virtue of the continuously marine facies, the Glossopteris-Gangamopteris association is 


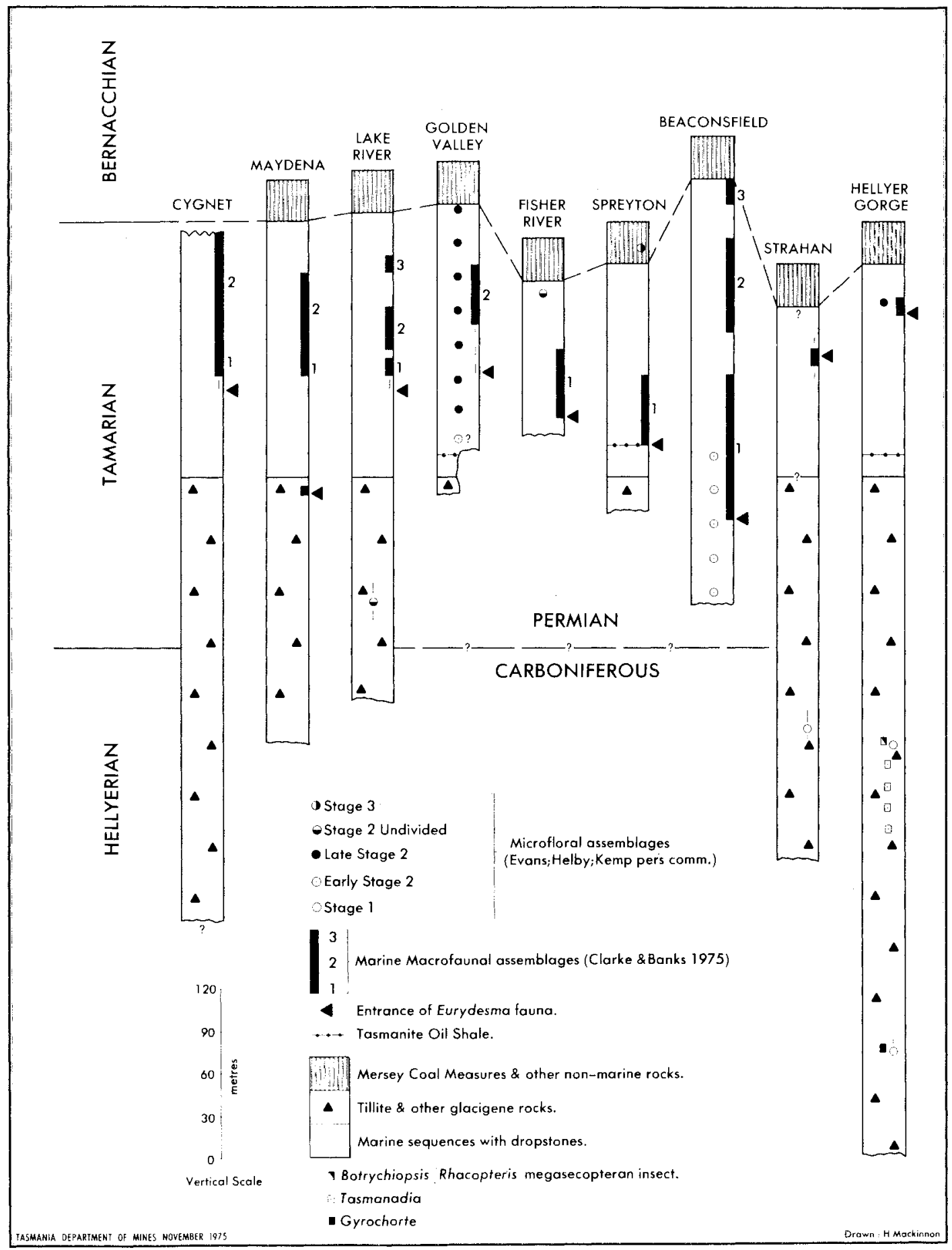

Fig. 3. - Comparative stratigraphic data for the lower parts of the Rekunian Series. 
poorly represented below the succeeding Bernacchian State, but rare specimens of Gangomopteris are known from early Tamarian horizons in several sequences (Woody Island Formation, south-eastern Tasmania, and Quamby Formation, Great Western Tiers).

Although the evidence is not conclusive, there are compelling grounds to suggest that the Stage 2 Microflora is the microfloral expression of the appearance of the Giossopteris-Gangamopteris association. If this is so, then both the Glossopteris and Eurydesma associations entered the Tasmanian sequence virtually contemporaneously (fig. 3).

Correlation and age

The Tamarian Stage is the Tasmanian equivalent of the Sydney Basin Allandale Fauna (Runnegar $1969 \mathrm{~b}$ et seq.) and its constituent zones (Runnegar and McClung 1975 ). Runnegar (1969b) discussed the correlation of the eastern and western Australian sequences, and concluded from the Western Australian ammonoid evidence that the Allandale Fauna is of late Asselian or early Sakmarian age. The Tamarian Stage is older than the New Zealand Telfordian Stage which is assigned to the Sakmarian (Waterhouse, 1967 et $\operatorname{seq}$.).

\section{Distribution}

Tamarian biota occur widely throughout Tasmania in a considerable variety of 1ithofacies. The predominant rock types include ill-sorted mudstone, siltstone and sandstone. Subordinate rock types include Tasmanite Oil Shale, glendonitic siltstone, coarse arkosic sandstone, limestone and coquinite. Glacially derived dropstones are always much in evidence.

\section{BERNACCHTAN STAGE}

Name Tasmania.

The name is derived from Bernacchi's Creek, near Darlington, Maria Island, East

\section{Reference section}

The section includes the 'Freshwater Beds'. 'Productus Zone' and 'Crinoidal Zone' (Banks 1958) as exposed in cliff and quarry sections near Darlington, Maria Island. The lowest part of the sequence is non-marine carbonaceous shale with abundant plant fossils, but the upper parts consist of compact calcareous siltstone and coarse crinoidal limestone with rich shelly marine faunas. Dropstones characterise the marine strata.

Biota

The lowest beds, which are everywhere non-marine, yield abundant Glossopteris, Gangamopteris and Noeggerathiopsis, and at Sassafras near Latrobe, the Mersey Coal Measures (in their type area) yield microfloras referable to Stage 3 (Kemp pers. comm.). Above this, diagnostic forms include Anidanthus springsurensis (Booker), Canerine zza farieyensis (Etheridge and Dun), Tdeniothaems subquadratus (Morris), Terrakea poltex Hill, Grantonia hobartensis Brown, Martiniopsis ovata (Campbel1), M. profunda (Campbel1), M. profunda (Campbel1), M. valida (Campbe11), Pseudosyrinx procera (Armstrong), and Thawmatoblastus Zongiramus Wanner. Other characteristic forms include Deltopecten spp., Eurydesma spp., Keeneia spp. and Calceolispongia, which are all survivors from the Tamarian Stage below; and Cladochonus, Thamnopora, Euryphy Zlum, Schuchertezla, Echinalosia preovalis (Maxwel1), Wyndhamia jikesi (Etheridge) - dalinondensis Booker, Cleiothyridina, Spirigerelta, Grantonia cracovensis Wass, Suleiplica tasmaniensis (Morris), Punctospinifer, Atomodesma (Aphanaia), Conocardiun, Megadesmus nobilissimus (de Koninck), ParaconuZaria dementensis (Johnston) and rare trilobites (Wass and Banks 1971), all of which survive into the Lymingtonian Stage above. Two zones can be recognised within the marine Bernacchian. They are a lower zone with 
Echinalosia preovalis pristina, and an upper zone with Taeniothaerus subquadratus. Both zones yield abundant Cancrinezza farteyensis.

Comments

Unfortunately marine sequences spanning the Tamarian-Bernacchian boundary are unknown in Tasmania. The base of the Bernacchian Stage is placed at the base of the freshwater sequence (Mersey Coal Measures and correlates) for three reasons:

(1) The base of the freshwater sequence is readily mappable throughout most of Tasmania.

(2) The freshwater beds yield microfloras referable to Stage 3.

(3) By biostratigraphic correlation with the Sydney Basin, the Tasmanian freshwater interval would (if marine) be expected to yield a branxtonensis zone assemblage (sensi Rumnegar and McClung, 1975). The affinities of brantonensis zone. (1ower Farley) assemblages are clearly with Bernacchian faunas rather than with Tamarian faunas.

The Bernachian Stage as defined is thus typified firstly by limited developments of coal measures and other nonmarine rocks, followed by the most pronounced development of carbonate

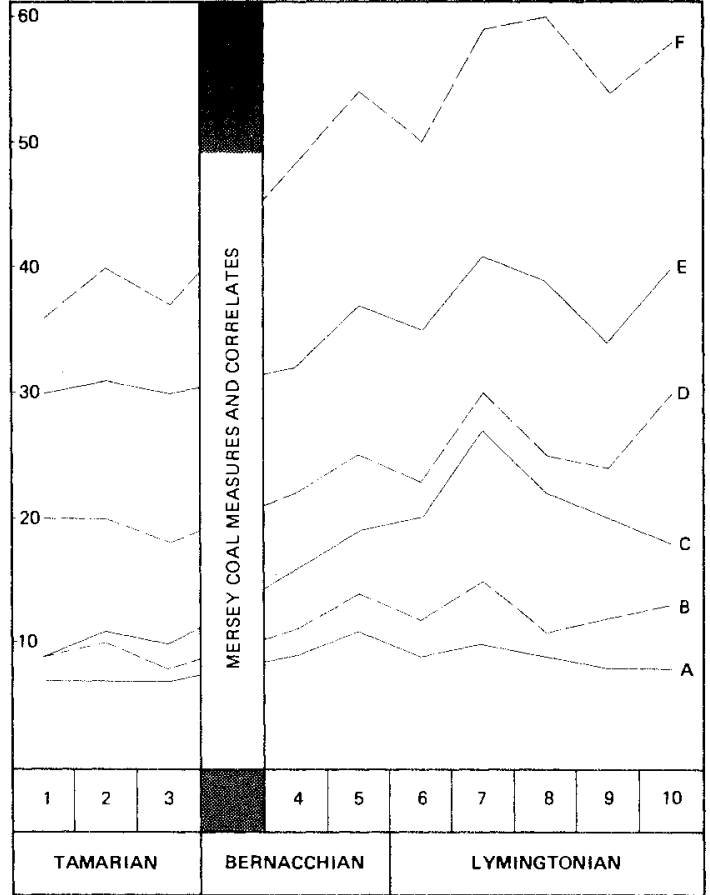

Fig. 4. - Frequency distributions of Rekunian marine macro-invertebrates. A. brachiopod families, B. brachiopod genera, C. brachiopod species, D. brachiopod and pelecypod genera, E. all genera, F. all species. sedimentation anywhere in the Tasman$i$ an sequence. These factors together with a small but definite increase in the taxonomic diversity of the marine macrofaunas (fig. 4), have been used to support a significant amelioration in climatic conditions (Waterhouse $1969,1970,1971$ ). However, the evidence is rather equivocal since dropstones are always present in marine Bernacchian sequences, the more so in wholly clastic detrital (and non-carbonate) sequences in the Maydena (Jago, 1972) and Frankford areas (Gulline, in press). Furthermore, the overlying Lymingtonian faunas display a slight$1 y$ greater taxonomic diversity, yet dropstones remain abundant, coal measures are absent, and carbonates are rare, thin and discontinuous. The most recent data presented by Waterhouse and Bonham-Carter (1975) now show substantial agreement as to the cool-water aspect of Tasmanian faunas.

Correlation and age

The Bernacchian Stage is the Tasmanian equivalent of Fauna $I$ and Fauna II in the Queensland Bowen Basin (Dickins et al:, 1964) and Fauna II in the Sydney Basin (Rumnegar, 1969) and their constituent zones (Runnegar and McClung, 1975). Runnegar (1969) discusses the corelation of the eastern and western Australian sequences and concluded 
from the ammonoid evidence that Fauna IJ ranges in age from late Sakmarian (Sterlitamakian) to early Artinskian (Aktastinian). The New Zealand Telfordian and Mangapirian Stages (Waterhouse, 1967) appear to be approximately equivalent with the Bernacchian Stage, but the basis for comparison is somewhat imprecise. The Mangapirian Stage may range beyond the limits of the Bernacchian Stage (Clarke and Banks, 1975).

Distribution

Early Bernacchian floras and microfloras are widely distributed throughout Tasmania (Mersey Coal Measures; Liffey Sandstone; Faulkner Group and correlates, see (fig. 5). Late marine Bernacchian faunas are less widely distributed but they are well-developed at Granton, Maydena, Frankford, Maria Island and much of North-east Tasmania. Southwards from Granton, Bernacchian rocks thin rapidly and disappear south of Snug (Farmer, in press) so that throughout the Cygnet area Lymingtonian sequences rest directly on incomplete Tamarian sequences.

\section{LYMINGTONIAN STAGE}

Name

The name is derived from Lymington, Huon River area, South-east Tasmania.

\section{Reference section}

The section includes unnamed formations of siltstone and sandstone (Farmer, in press), and Ferntree Group as exposed at Deep Bay, Cygnet area, Huon River (Clarke and Banks 1975 ; Farmer in press). The sequence consists predominantly of compact, illsorted siltstone and sandstone, with subordinate coarse-grained, cross-bedded sandstone (Risdon Sandstone) and other thin, coarse-grained, gritty arkosic layers. Dropstones occur more or less abundantly throughout. Marine fossils are very common particularly in the lower parts of the section, but decrease in abundance towards the top where worm burrows and other biogenic structures predominate.

The Deep Bay section realises most of the attributes of the ideal stratigraphic section. It is continuously exposed and unfaulted, continuously fossiliferous, the fossils are well-preserved, and for most part, there are no abrupt changes in lithology. Unfortunately, the base of the section is not exposed. However, diamond drilling and other coastal sections in the Cygnet area indicate that Bernacchian strata are wholly absent so that Lymingtonian rocks rest on an incomplete Tamarian sequence. This difficulty can be resolved by virtue of the fact that the top of the Maria Island Bernacchian section can serve as the base of the Lymingtonian Stage. Biostratigraphic details indicate that no significant or substantial portion of the Deep Bay section is missing.

Biota

Fossils are abundant at many levels throughout the Lymingtonian Stage. Their abundance decreases upwards but definitive and well-preserved faunas are known from many localities only a few metres below the top of the Stage (Clarke 1973). One of these at Point Puer, is the locality from which Terrakea brachythaera was originally described (Morris, in Strzelecki 1845). Diagnostic forms which range throughout include Terrakea brachythaera (Morris), Martiniopsis ingeZarensis (Campbel1), Fleteherithymis parkesi (Campbe11), Gilledia ulladulzensis (Campbel1), Astartiza intrepida (Dana), Myonia corrugata (Fletcher) and Vacunelza curvata (Morris). Other characteristic but shorter-minging species include Echinalosia ovalis (Maxwe11), Terrakea concava (Waterhouse), Aperispimifer wairakiensis (Waterhouse, Fusispirifer avicula (Morris), an important evolutionary lineage of Martiniopsis through $M$. plana (Campbeli) $M$. brevis McClung and Armstrong - M. undulosa (Campbe11), M. isbe 27i (Campbel1), $M$. angulata (Campbel1), M. globosa (Campbe11), M. strzeleckii (do Koninck), Sulciplica transversa Waterhouse, Plekonelza acuta (Campbel1), Astartelia, Etheripecten leniusculus, Warthia micromphala (Morris) and Walnichollsia subcancellata (Morris). It is the restricted vertical distributions of these more short-ranged species, together with 


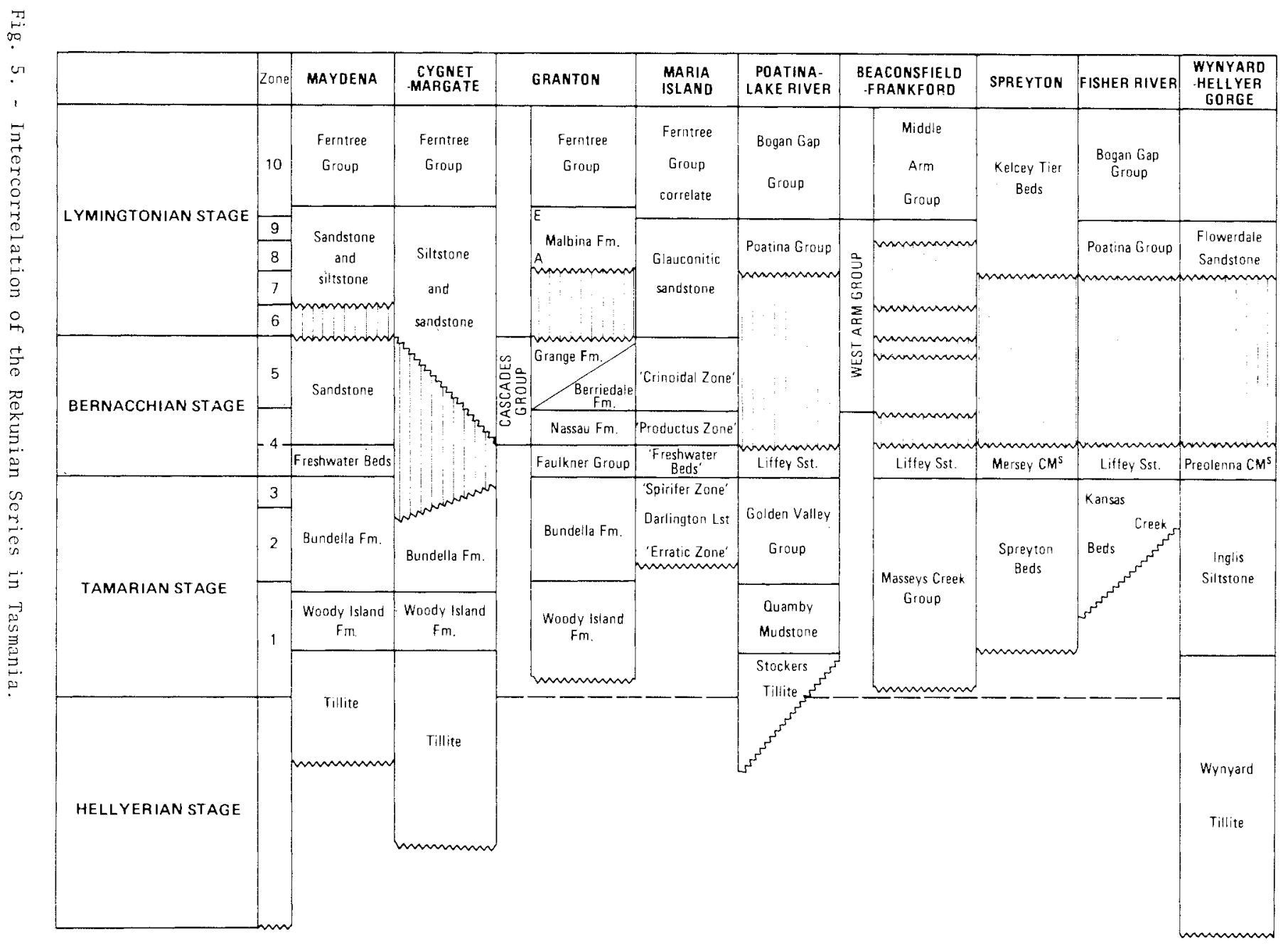


the disappearance of certain long-ranged Tamarian and Bernacchian species and genera such as Deltopecten, Eurydesma, Echinalosia preovalis, Wypdhamia dalwoodensis, Cleiothypidina, Punctospirifer, Grantonia cracovensis, and Sulciplica tasmaniensis, which allow the recognition of the five zonal assemblages (Clarke and Banks 1975) which comprise the Lymingtonian Stage. These are, in ascending order:- the zone of Martiniopsis plana (with Eurydesma and Deltopecten), the zone of Martiniopsis brevis (with Eurydesma, Deltopecten and Terrakea concava), the zone of Martiniopsis undulosa (with Deltopecten and Terrakea concava), the zone of Martiniopsis isbezli (with Deltopecten), and the zone of Echinalosia ovalis and Megadesmus grandis. Poorly-preserved plants occur sporadically throughout the Stage. Abundant and well-preserved Glossoptemis, Gangamopteris and other. plants occur in the Cygnet Coal Measures, Jackey Formation and correlates, but these are beyond the limits of the Rekunian Series (Forsyth et al. 1974).

\section{Correlation and age}

The Lymingtonian Stage is the Tasmanian equivalent of the New Zealand Braxtonian Stage (Waterhouse 1967); of Fauna III and Fauna IV in the Queensland Bowen Basin (Dickins et al. 1964); and of the Ulladulla Fauna and Fauna IV in the Sydney Basin (Runnegar 1969) and their constituent zones (Runnegar and McClung 1975). The early Lymingtonian is probably of late Artinskian (Baigendzhinian) age since ammonoids of this age occur in the lower parts of Fauna III in Queensland (Armstrong et al. 1967). The late Lymingtonian may be as young as Kazanian since a Kazanian age is generally accepted for Fauna IV in eastern Australia (Dickins 1968, 1970; Runnegar 1969b), and a Kazanian age is advocated for the Late Braxtonian (Flettian) Stage in New Zealand (Waterhouse 1969 et seq.).

\section{Distribution}

Lymingtonian biota are widespread throughout Tasmania. Characteristically they occur in more or less strongly bioturbated and ill-sorted siltstone and sands tone. Lesser developments of limestone, calcareous siltstone, bryozoal shale, coarse arkosic sandstone and conglomerate, glauconitic sandstone and quartz conglomerate also occur. Glacially derived dropstones occur throughout.

\section{SUMMARY AND CONCLUSIONS}

Four stages are erected within the predominantly marine Tasmanian Late Palaeozoic (Permo-Carboniferous) Rekunian Series. The basal Hellyerian Stage is represented entirely by thick sequences of glacigene rocks which are poorly fossiliferous. However, the biota presently known indicate that, in Tasmania, the main Gondwanan glacial episode reached its climax no later than Stephanian, and almost certainly pre-dated the appearance of the Eurydesma and GLossoptemis associations. The Tamarian, Bernacchian and Lymingtonian Stages are represented predominantly by marine sequences with abundant glacially derived dropstones. The Tasmanian lithostratigraphic and biostratigraphic details indicate a consistently cold- to cool-water environment with perhaps a slight and gradual upward amelioration in conditions until the end of marine sedimentation.

\section{ACKNOWLEDGEMENTS}

The authors would like to thank Dr. E. Williams for constructive criticism of the manuscript. They would a1so like to thank Dr. E.M. Kemp, Bureau of Mineral Resources, Canberra, and Dr. R.J. Helby, formerly Geological Survey of New South Wales, for age assessments of microfloral assemblages and other palynological advice. Dr. R.E. Gould, University of New England, identified the specimens of Botmychiopsis.

Both authors publish with the permission of the Director of Mines, Tasmania. 


\section{REFERENCES}

Armstrong, J.D., 1968: Synonomy of the Australian spiriferid genera Trigonotreta Koenig, 1825, and Grantonia Brown, 1953. J. geol. Soc. Aust. 15, 79-86.

, 1970: Syringothyrid brachiopods from the Permiar of eastern Australia. N. Jb.geol. PaZaeont.Abh. (Stuttgart), 136 (2), 135-165.

., Dear, J.F., and Runnegar, B., 1967: Permian ammonoids from eastern Australia. J.geol.Soc.Aust., 14, 87-98.

Banks, M.R., 1958: Recent additions to knowledge of the Permian System in Tasmania. Symposium on Gonduanaland, 20th Int.geol.Congr., Mexico, 151-177.

., 1962: Permian System, in Spry, A., and Banks, M.R., (Ed.)., GEOLOGY OF TASMANIA. J. geol Soc.Aust., 9, 189-215.

Booker, F.W., 1929: Preliminary note on new subgenera of Productus and Strophazosia from the Branxton district. J. Proc.R.SOE.N.S.W., 63, 24-32.

Campbe11, K.S.W., 1959: The Martiniopsis-1ike spiriferids of the Queensland Permian. Palaeontology, 1, 333-350.

- 1960: 'The Brachiopod genera Ingezarezla and Notospipifer in the Permian of Queensland. J.PaZeont., 34, 1106-1123.

., 1961: New species of the Permian spiriferoids Ingezarezza and Notospirifer from Queensland, and their stratigraphical implications. Palaeontographica A., 117, 159-192.

., Australian Permian Terebratuloids. BuzZ.Bur.Miner.Resour.Geol. Geophys.Aust., 68, 1-146.

Carey, S.W., and Ahmad, N., 1961: Glacial marine sedimentation. In Rassch, G.O. (Ed.), Geology of the Arctic, 2, 865-894. Proc.1st Inst.Symp. Aretic Geol.

Clarke, M.J., 1973: Faunas from the Ferntree Group of south-eastern Tasmania. Tech.Rep.Dep.Mines Tasm., 16, 50-65.

., 1974: Certain misconceptions regarding Late Palaeozoic rocks in Tasmania. Geol.Mag., 111, 565-566. SuYv.Tasm.

., in Gee, R.D., and Legge, P.J., 1974: Beaconsfield. Explan.Rep.geol.

., and Banks, M.R., 1975: The stratigraphy of the lower (Permo-Carboniferous) parts of the Parmeener Super-Group, Tasmania. In Campbe11, K.S.W. (Ed.) GONDWANA GEOLOGY. Froc. 3rd Gonduana Symp., Canberra, 453-467.

Crockford, J., 1951: The development of bryozoan faunas in the Upper Palaeozoic of Aistralia. Proc.Linn.Soc.N.S.W., 76, 105-122.

Dear, J.F., 1972: Preliminary biostratigraphic subdivision of the Permian faunas in the northern Bowen Basin, and their distribution throughout the Basin. Rep.geol. Surv. Qd, $49,1-19$.

, 1972b: Strophomenoid brachiopods from the higher Permian faunas of the Back Creek Group in the Bowen Basin. Publs geol.Sum.Qd, 347, 1-39. 


\section{M.J. Clarke and N. Farmer}

Dickins, J.M., 1956: Permian pelecypods from the Carnarvon Basin, Western Australia. Bulz. Bur.Miner.Resour.Geol.Geophys.Aust., 29, 1-42.

., 1957: Lower Permian pelecypods and gastropods from the Carnarvon Basin, Western Australia. Bulz.Bur.Miner.Resour. Geol.Geophys. Aust. 41. 1-74.

., 1963: Permian pelecypods and gastropods from Western Australia. Buzz.Bur.Miner. Resour.Geol. Geophys.Aust., 63, 1-203.

., 1964: Correlation and subdivision of the Permian of western and eastern Austra1ia. Rep.22nd Int.geol.Congr., India, 8, 39-49.

., 1968: Correlation of the Permian of the Hunter Valley, New South Wales, and the Bowen Basin, Queensland. Bulz.Bur.Miner.Resour.Geol.Geophys.Aust., 80, $27-44$.

., 1970: Correlation and subdivision of the Permian of western and eastern Australia. Buzz.Bur.Miner.Resour.Geol.Geophys.Aust., 116, 17-27.

., Malone, E.J., and Jensen, A.R., 1964: Subdivision and correlation of the Permian Middle Bowen Beds, Queensland. Rep.Bur.Miner, Resour. Geol. Geophys. Aust., $70,1-12$.

Dun, W.S., 1912: Marine fossils from the Tasmanite Spore Beds of the Mersey River. Rec.geol.Surv.Tasm. 1 .

Etheridge, R., 1880: Report on a collection of fossils from the Bowen River coalfielo and the limestone of the Fanning River, northern Queensland. Froc.R.phys.Soc. Edinb., 5, 263-328.

Evans, P.R., 1969: Upper Carboniferous and Permian palynological stages and their distribution in eastern Australia. GONDWANA STRATIGRAPHY, 2, UNESCO, Paris 41-54.

Farmer, N., in press: Geological Atlas, 1:50 000 Series, Zone 7, Sheet 88, Kingborough. GeoZ.Surv.Tasm.

F1etcher, H.O., 1958: The Permian gastropods of New South Wales. Rec.Aust.Mus., 24, $115-162$.

Forsyth, S.M., Farmer, N., Gulline, A.B., Banks, M.R., Wil1iams, E., and C1arke, M.J. 1974: Status and subdivision of the Parmeener Super-Group, Tasmania. Pap.Proc. R.Soc.Tasm., 108, 107-109.

Gee, R.D., and Legge, P.J., 1974: Beaconsfield. Explan.Rep.geoZ.Surv.Tasm.

Helby, R.J., 1969: The Carboniferous-Permian boundary in eastern Australia: an interpretation on the basis of palynological information. Spec.Pubzs.geol.Soc.Aust., 2, $69-72$.

Hi11, D., 1950: The Productinae of the Artinskian Cracow fauna of Queensland. Pap. Dep.geol. Uni.Qd., 3, (2), 1-36.

., 1952: The Gondwana System in Queensland. In, Symposium sur Zes series de Gondwana, 19th Int. Ceol.Congr., Algiers, 35-49.

Irving, E., 1966: Palaeomagnetism of some Carboniferous rocks from New South wales and its relation to geological events. J.geophys.Res., 71, 6025-51. 
Kemp, E.M., 1975: The palynology of Late Palaeozoic glacia1 deposits of Gondwanaland. In Campbel1, K.S.W. (Ed.) GONIJWANA GEOLOGY. Proc. 3rd Gondwana Symp., Canberra, $397-413$.

Jago, J.B., 1972: Geology of the Maydena Range. Pap.Proc.R.Soc.Tasm. 106, 45-56.

Johnston, R.M., 1887: Contributions to the palaeontology of the Upper Palaeozoic rocks of Tasmania. Porp.Proc.R.SOC.Tasm., (1886), 4-18.

Hobart. ., 1888: SYSTEMATIC ACCOUNT OF THE GEOLOGY OF TASMANIA. Gov't Printer,

Koenig, C., 1825: Icones Fossilium Sectiles, London. 1-4.

Maxwe11, W.G.H., 1954: StrophaZosia in the Permian of Queensland. J.PaZeont., 28, 533-559.

McClung, G.R., and Armstrong, J.D., 1975: New species of Martiniopsis (Brachiopoda, Spiriferida) from the Permian of eastern Australia, Qd Gov't Min.J., 76, 231-234.

McDouga11, I., and Leggo, P.J., 1965: Isotopic age determinations on granitic rocks from Tasmania. J.geol.Soc.Aust., 12, 295-332.

Morris. T., 1845: Description of fossi1s In, Strzelecki, P.E., PHYSICAL DESCRIPTION OF NEW SOUTH WALES AND VAN DIEMENS LAND, 270-291. Longman, Brown and Longmans : London .

Riek, E., 1973: A Carboniferous insect. Nature (Phys.Sci.), 244, (No. 5416), $455-456$.

Runnegar, B., 1965: The bivalves Megadesmus Sowerby and Astartiza Dana from the Permian of eastern Australia. J.geol.Soc.Aust., 12, 227-252.

., 1967a: Preliminary faunal zonation of the eastern Australian Permian. Qd Gov't Min.J., 68, 552-556.

., 1967b: Desmondont bivalves from the Permian of eastern Australia. Bulz.Bur.Miner. Resour.Geol.Geophys.Aust., 96, 1-108.

., 1969a: Permian fossils from the southern extremity of the Sydney Basin. In Campbe11, K.S.W. (Ed.), ST'RATIGRAPHY AND PALAEONTOLOGY : ESSAYS IN HONOUR OF DOROTHY HILL. A.N.U. Press : Canberra, 176-298.

., 1969b: The Permian faunal succession in eastern Australia. Spec.Pubzs. geol.Soc.Aust., 2, 73-98.

., 1970: Eurydesma and GZendezza gen. nov. (Bivalvia) in the Permian of Eastern Australia. Bulz. Bur.Miner.Resour.Geol.Geophys.Aust., 116, 83-118.

., 1972: Late Palaeozoic Bivalvia from South America: provincial affinities and age. An.Acad, Brasiz, Cienc., 44, 295-312.

., and McClung, G., 1975: A Permian time scale for Gondwanaland. In Campbe11, K.S.W. (Ed.), GONDWANA GEOLOGY. Proc. 3rad Gondwana Symp., Canberra, $425-441$.

Thomas, G.A. 1971: Carboniferous and Early Permian brachiopods from Western and Northern Australia. Buzz.Bur.Miner.Resour.Geol.Geophys.Aust., 56, 1-276. 
Wass, R.E., 1968: Permian Polyzoa from the Bowen Basin. Bulz.Bur.Miner.Resour.Geol. Geophys. Aust., 90, 1-134.

., 1969: Australian Permian polyzoa faunas: distribution and implications. In Campbe11, K.S.W. (Ed.), STRATIGRAPHY AND PALAFONTOLOGY, ESSAYS IN HONOUR OF DOROT'HY HILL. A.N.U. Press, Canberra, 236-245.

and Banks, M.R., 1971: Some Permian trilobites from eastern Austra1ia. Pataeontology, 14, 222-241.

Waterhouse, J.B., 1964: Permian brachiopods of New Zealand. PaZaeont.BuZZ.geol.Surv. N.Z., $35,1-287$.

., 1967: Proposal of series and stages for the Permian in New Zealand. Trans.R.SoC.N.Z. (Geol.) 5, 161-180.

., 1968: The classification and descriptions of Permian Spiriferida (Brachiopoda) from New Zealand. Palaeontographica A., 129, 1-94.

., 1969: World correlations of New Zealand Permian Stages. N.Z. J.Geol.Geophys., 12, 713-737.

., 1970: The world significance of New Zealand Permian stages. Trans. R.SOC.N.Z. (Geol.) 7, 97-109.

., 1971: Correlation of the marine Permian faunas for Gondwana. In Haughton, S.H. (Ed.), Proc.Pap. 2nd Gonctwana Symp., South Africa. C.S.I.R., Pretoria, 381-394.

., and Bonham-Carter, G.F., 1975: Globa1 distribution and character of Permian biomes based on brachiopod assemblages. Can.J.Earth.Sci., 12, (7), $1085-1146$. 


\section{Appendix}

Rekunian marine macro-invertebrates and their zonal distributions. The zones are numbered in upward sequence from 1-10. First and last appearances are given. Certain less abundant species have not necessarily been recorded from each individual zone throughout their total ranges. The common species are indicated by asterisks.

\section{Brachiopods}

orbiculoidea sp. 6

Schuchertezza sp. 1-8.

* Streptorhynchus sp. nov. 1

Costalosia apicallosa Clarke 2

Echinalosia maxwelli (Waterhouse) 7-8

* Echinalosia ovalis (Maxwe11) 10

Echinalosia preovalis (Maxwe11) 4-8

*Echinalosia preovalis pristina (Maxwe11) 4

* Strophalosia subcircularis $\mathrm{Cl}$ arke and variants $2-3$

* Strophalosia sp. nov. 1

Wyndhamia irregularis C1arke 2

* Wyndhamia jukesi (Etheridge) 4-5

* Wyndhomia dalwoodensis Booker 5-9

* Taeniothaerus subquadratus (Morris) 5

Anidanthus springsurensis (Booker) 5

Anidanthus sp. 7-8

*Cancrinezza farleyensis (Etheridge and Dun) 4-5

* Terrakea brachythaera (Morris) 6-10

*Terrakea concava Waterhouse 7-8

Terrakea dickinsi Dear 5-6

Terrakea polzex Hill 5

Cleiothyridina sp. 5-7

Spirigerelza sp. 5-8

* Aperispirifer wairakiensis (Waterhouse) 6-8

*Aperispirifer Zethamensis Waterhouse 7-10

*Fusispirifer avicula (Morris) 9-10

Fusispirifer sp. nov. 7-9

Grantonia cracovensis Wass 5-8

* Grantonia hobartensis Brown 4-5

Sulciplica phazaena (Dana) 7-10

* Sulciplica stutchburiz Auctt. 3-7

* Sulciplica transversa Waterhouse 7-10

* Sulciplica sp. nov. 3

*Trigonotreta stokesi Koenig 1-3

*Martiniopsis angulata (Campbe11) 6-10

*Martiniopsis brevis McClung and Armstrong 7

* Martiniopsis elongata McClung and Armstrong 1

Martiniopsis globosa (Campbe11) 10

Martiniopsis ingelarensis (Campbel1) 6-10

* Martiniopsis isbelzi (Campbe11) 9

*Martiniopsis konincki Etheridge 2-3

*Martiniopsis magna (Campbel1) 6-10

*Martiniopsis ovata (Campbel1) 4-5

*Martiniopsis plana (Campbe11) 6

* Martiniopsis plica (Campbell) 6-7

*Martiniopsis profunda (Campbel1) 4-5

*Martiniopsis strzeleckii de Knoinck 6-9

*Martiniopsis undulosa (Campbel1) 8

Martiniopsis valida (Campbe11) 5 
Martiniopsis sp. nov. A (coarsely plicate) 7-8

*Martiniopsis sp. nov. B (giganteid form) 10

Notospirifer extensus Campbell 6

Notospirifer minutus Campbel1 9-10

'Spirifer' duodecemcostatus M'Coy 9-10

* Notospiriferid gen.nov. 10

Cyrtella nagmargensis australis Thomas 1

* Pseudosyminx alzandalensis Armstrong 1-3

Pseudosyminx procera (Armstrong) 4-5

'Pseudosyminx' ulzadulzensis (Armstrong) 6-8

'Pseudosyminx' spp. $9-10$

Punctospirifer austraitis (Etheridge) 4-7

Punctospirifer etheridgei Armstrong 6-9

Plekonelza acuta Campbe11 10

Rhynchonel1id indet. 5

* Fetcherithymis amygdala (Dana) 6-10

* Fetcherithymis farleyensis Campbel1 4-5

*Fletchemithyris parkesi Campbell 6-10

Fletcherithyris reidi Campbe11 5-8

* Fletcherithyris spp. 1-10

Gilledia homevalensis Campbe11 4-5

*Gizledia oakiensis Campbe11 6-8

Gizledia ulzaduzlensis Campbel1 6-10

*Gilzedia spp. 1-10

\section{Pelecypods}

Astartelza sp. 7

* Astartila intrepida (Dana) 6-10

*Atomodesma (Aphonaia) sp. 4-10

* DeZtopecten izlowarensis (Morris) 1-9

*Deltopecten limaeformis (Morris) 4-9

Deltopecten squam-iifems (Morris) 5-8

Deltopecten waterfordi Dickins 1-3

Etheripecten farteyensis (Etheridge and Dun) 5-8

*Etheripecten fittoni (Morris) 5-10

*Etheripecten leniusculus (Dana) 9-10

*Etheripecten tenuicollis (Dana) 1-3

* theripecten spp. 1-10

* Eurydesma cordatum Morris 2

* Eury desma hobartensis (Johnston) 1-7

Eurydesma playfordi Dickins 2

* Eurydesma spp. 1-7

*Megadesmus grandis (Dana) 10

*Megadesmus gryphoides (de Koninck) 6-10

*Megadesmus nobilissimus (de Koninck) 4-8

Megadesmus pristinus Runnegar 1

Megadesmus sp. 2-3

Merismopteria carrandibbiensis (Dickins) 1-8

* Merismopteria macroptera (Morris) 10

* Merismopteria sp. 1-10

*Myonia carinata (Morris) 6-10

* Myonia corrugata Fletcher 6-10

Myonia elongata Dana 3

*Myonia mormisi (Etheridge) 1-3

* Myonia triangulata (Waterhouse) 10

Nuculopsis (Nuculopsis) sp. 10

Oriocrassatelza sp. 10 
Phestia dawini (de Koninck) 1

Phestia sp. 10

Pleurikodonta elegans Runnegar 10

Promytizus cancelzatus Maxwe11 1

*Pyramus Zaevis ( $\mathrm{J}$. Sowerby) 1-3

Pyromus myiformis (Dana) 9-10

* Schizodus australis (Runnegar) 1-3

Schizodus spp. 4-10

StrebZochondria sp. 4-8

*Streb Lopteria spp. 2-10

* Stutchburia costata (Morris) 8-10

* Stutchburia compressa (Morris) 6-10

Stutchburia cuneata (Dana) 10

'Stutchburia' edelfeiti (Etheridge) 10

* Stutchburia spp. 1-10

* Vacunelza curvata (Morris) 6-10

Volselzina mytiliformis (Etheridge) 8

Pelecypod gen. nov. 7-8

Gastropods

*Keeneia ocula (J. Sowerby) - platyschismoides Etheridge 1-10

Keeneia trochiforme F1etcher 5-8

* Keeneia twelvetreesi Dun 1-3

Mourtonopsis straeleckiana Morris 10

Paromphalus cormonitiformis (Etheridge) 1-3

*Peruvispira spp. 1-10

*Ptychomphazina spp. 1-10

Rhabdocantha sp. 3

Strotosoma sp. 7-8

*Walnichollsia subeancellata (Morris) 7-10

* Warthia mieromphala (Morris) 9-10

Rostroconchs

Conocardium sp. $4-10$

Hyolithids

Hyolithes sp. 8-10.

Cepha1opods

Michelinoceratid nautiloids 5-8

Coelenterates

Notoconularia spp. 2-10

* Paraconuzaria derwentensis (Johnston) 5-8

Paraconcularia sp. 2-8

Cladochonus nicholsoni (Etheridge) 5-8

Thamopora wilkinsoni Etheridge 5-8

Euryphyzzum spp. 4-10

?Plerophyzzum sp. 5

\section{Echinoderms}

Thaumatoblastus Zongiramus Wanner 5 
Blastoid indet. 8

Calceolispongia sp. 1-5

Comptocrinus sp.. 3-5

Jimbacrinus sp. 1-2

Phialocrinus sp. 10

Trilobites

Doublatiasp. 4-8

Bryozoans

Fenestelza canthariformis Crockford 6-10

* Fenestella dispersa (Crockford) 1-10

* Fenestelza fossuza Lonsdale 1-10

Fenestella granulifera (Crockford) 4-8

Polypora magnafenestrata Crockford 5

Polypora woodsi (Etheridge Jr) 4-5

Protoretepora ampla Lonsdale 1-5

Stenodiscus sp. 5

* Stenopora crinita Lonsdale 4-10

* Stenopora ovata Lonsda1e 1-10

* Stenopora tasmoniensis Lonsdale 1-3

* Streb zocascopora marmionensis (Bretna11) 1-5 